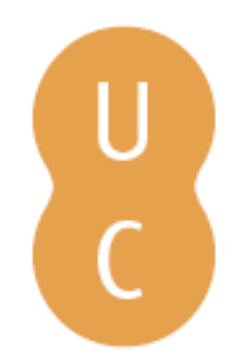

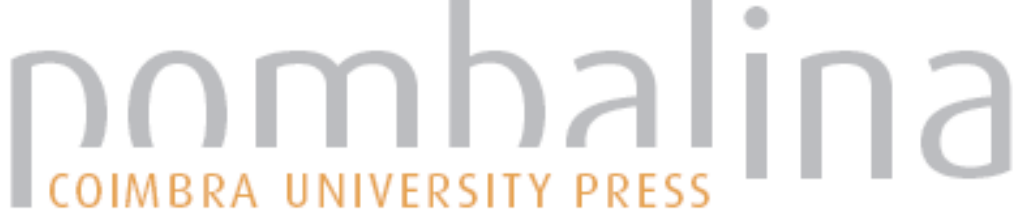

\section{Da natureza cosmopolita de Orfeu}
Autor(es):
Pires, Antônio Donizeti
Publicado por: Imprensa da Universidade de Coimbra; Annablume
URL persistente:
URI:http://hdl.handle.net/10316.2/40861
DOI:
DOI:https://doi.org/10.14195/978-989-26-1288-1_6

Accessed : $\quad$ 26-Apr-2023 05:05:47

A navegação consulta e descarregamento dos títulos inseridos nas Bibliotecas Digitais UC Digitalis, UC Pombalina e UC Impactum, pressupõem a aceitação plena e sem reservas dos Termos e Condições de Uso destas Bibliotecas Digitais, disponíveis em https://digitalis.uc.pt/pt-pt/termos.

Conforme exposto nos referidos Termos e Condições de Uso, o descarregamento de títulos de acesso restrito requer uma licença válida de autorização devendo o utilizador aceder ao(s) documento(s) a partir de um endereço de IP da instituição detentora da supramencionada licença.

Ao utilizador é apenas permitido o descarregamento para uso pessoal, pelo que o emprego do(s) título(s) descarregado(s) para outro fim, designadamente comercial, carece de autorização do respetivo autor ou editor da obra.

Na medida em que todas as obras da UC Digitalis se encontram protegidas pelo Código do Direito de Autor e Direitos Conexos e demais legislação aplicável, toda a cópia, parcial ou total, deste documento, nos casos em que é legalmente admitida, deverá conter ou fazer-se acompanhar por este aviso. 


\section{Cosmópolis}

\section{mobilidades culturais às origens do pensamento antigo}

Gabriele Cornelli, Maria do Céu Fialho e Delfim Leão

\section{(coords.)}

IMPRENSA DA UNIVERSIDADE DE COIMBRA 


\section{Da natureza cosmopolita de Orfeu}

(The cosmopolitan nature of Orpheus)

\section{Antônio Donizeti Pires (adpires@fclar.unesp.br) UNESP/Araraquara; UnB - Cátedra Archai UNESCO; bolsista CAPES/FCT}

Resumo: Em termos mitológicos e literários, quatro são os mitemas que fundamentam a narrativa de Orfeu: a) sua participação na viagem dos Argonautas em busca do Velocino de Ouro; b) seu casamento com a ninfa Eurídice, embora esta logo the seja arrebatada pela morte; c) sua catábase ao Hades, aonde vai para tentar reaver a amada dos mortos: ele o consegue, mas sua desobediência aos deuses infernais faz com que perca Eurídice definitivamente; d) sua morte violenta, esquartejado pelas enciumadas Bacantes da Trácia. No esquema, sobressai o Orfeu portador da lira, herói civilizador, cujo poder de sedução encanta animais, pedras, plantas, homens e deuses. Os quatro mitemas apontam também para uma configuração em gérmen dos gêneros literários, pois o primeiro é nitidamente épico e os três restantes conotam aspectos líricos e dramáticos do ciclo mítico. Enfim, o Orfeu sacerdote seria fundador do culto de mistérios que leva seu nome, o Orfismo, que gozou de grande reputação durante o cosmopolita período helenístico da cultura grega. Pelo exposto, dado o fato de o mito de Orfeu ter transitado também pela filosofia e pelas artes, o que se pretende é rastrear, fundamentando-as, algumas de suas migrações pela cultura greco-latina.

Palavras-chave: Orfeu; Orfismo; mitemas

АвsтrAct: In mythological and literary terms, four are the mythemes that underlie the narrative of Orpheus: a) his participation in the trip of the Argonauts in search of the Golden Fleece; b) his marriage with the nymph Eurydice, who is soon swept away by death; c) his katabasis to Hades, where he went to try to get the beloved among the dead: he is successful, but his disobedience to the infernal gods causes him to lose Eurydice definitely; d) his violent death, quartered by the jealous Maenads of Thrace. In this plot, Orpheus stands out as bringer of the lyre and civilizing hero, and his power of seduction enchants animals, stones, plants, men and gods. The four mythemes also point, in outline, to a configuration in terms of literary genres, because the first is clearly epic and the three remaining explore lyric and dramatic aspects of the mythic cycle. Anyway, Orpheus as priest would be the founder of the mystery cults named Orphism, which enjoyed great reputation during the cosmopolitan Hellenistic period. Therefore, given the fact that the myth of Orpheus made its way also through philosophy and the arts, the intention of this paper is to trace and ground in it some migrations of Orpheus through Greek and Latin culture.

KeYwords: Orpheus; Orfism; mythemes

\section{Prelúdio}

À guisa de introdução, transcrevo uma breve antologia de Orfeu, pinçando 
aleatoriamente autores do passado e do presente, com o fito de nos situarmos em relação ao cosmopolitismo e à universalidade desse mito essencial, e a fim de frisar a mútua nutrição entre mitologia e literatura, na Grécia antiga. $\mathrm{O}$ primeiro texto é o "Fragmento 25 Page", do poeta Íbico de Régio (séc. VI a. C.), talvez o mais recuado testemunho sobre o poeta lendário, que já o qualifica, àquela altura, como um nome glorioso e arquiconhecido. Já o "Fragmento 62 Page", de Simônides (sécs. VI-V a. C.), revela-nos alguns dos atributos mais comuns de Orfeu:

Inúmeras, as aves voavam

sobre a sua cabeça

e os peixes, em pé, saltavam das águas de anil do mar, ao som do seu belo canto. ${ }^{1}$

Motivo complementar a este e que também parece recorrente no mundo antigo é o que alude à capacidade de Orfeu de arrastar os seres humanos empós de si, sob o efeito encantatório de sua voz. O motivo foi utilizado, por exemplo, na filosofia e na tragédia, se bem que em contextos diferentes: nas palavras iniciais do Protágoras, de Platão (sécs. V-IV a. C.), o filósofo de Atenas, não sem ironia, compara os seguidores do sofista com os seguidores do Orfeu sacerdote e fundador de mistérios (315a-315b). O desprezo e o repúdio de Platão (na República, por exemplo) não é exatamente contra Orfeu e alguns postulados do orfismo religioso (que redimensionou, fazendo destes os fundamentos de sua própria filosofia, segundo advogam Francesc Casadesús Bordoy ${ }^{2}$ ou Alberto Bernabé ${ }^{3}$ ), mas contra aqueles supostos seguidores do bardo que enganavam o povo através da má reputação, da cobiça e do charlatanismo. Veja-se, no fragmento, a comparação entre os dois líderes:

Atrás destes [discípulos] seguiam outros, a prestar atenção à conversa, e que me pareciam na maior parte estrangeiros, daqueles que Protágoras traz consigo de todas as cidades por onde passa, encantando-os com a sua voz, como Orfeu: e eles, sob este encanto, lá vão atrás da voz. ${ }^{4}$

No caso da tragédia Agamémnon, de Ésquilo (sécs. VI-V a. C.), o motivo serve para, comparando e enaltecendo a voz divina do bardo, realçar a insensatez do juízo e da fala humana: "A tua língua é o contrário da de Orfeu: enquanto este arrastava tudo atrás de si pelo encanto da sua voz, tu irritas quem te ouve com o teu ladrar insensato." ${ }^{5}$

\footnotetext{
${ }^{1}$ Simônides apud Pereira 2009: 179.

${ }^{2}$ Dos inúmeros estudos do Professor sobre o tema, veja-se Casadesús Bordoy 2013: 71-87.

${ }^{3}$ Dos inúmeros estudos do Professor sobre o tema, veja-se Bernabé 2011.

${ }^{4}$ Platão apud Pereira 2009: 420.

${ }^{5}$ Ésquilo 1991: 97.
} 
No que tange à catábase de Orfeu ao Hades em busca de Eurídice, o escritor e filósofo Sêneca (4 a. C.-65 d. C.), no primeiro estásimo (coro de tebanos) de sua tragédia A loucura de Hércules, recorda-a demoradamente (v. 569-591) porque o bravo Héracles também precisou descer ao Inframundo para cumprir um de seus trabalhos (no caso, subjugar o cão Cérbero, o guardião do Hades, e trazê-lo à luz do dia):

Orfeu pôde dobrar os ferozes senhores das sombras com cânticos e preces suplicantes, enquanto resgatava sua Eurídice.

A arte que atraía florestas, aves e rochedos, que provocara o retardamento dos rios e a cujo som as feras se imobilizaram, abranda os Infernos com vozes insólitas e ressoa com mais clareza nos lugares silenciosos.

Choram Eurídice as mulheres da Trácia, choram-na os deuses pouco afeitos às lágrimas; e os juízes que, com o cenho excessivamente carregado, investigam crimes e derrubam velhos réus, sentam-se chorando Eurídice.

'Fomos vencidos', diz finalmente o árbitro da morte, 'vai para as regiões superiores, porém sob a força desta lei: tu, como acompanhante, avança atrás de teu marido; quanto a ti, não olhes para a tua esposa antes que o dia claro se apresente aos deuses e apareça a porta do espartano Tênaro'.

$\mathrm{O}$ verdadeiro amor odeia os retardamentos e não os tolera; porque se apressou para ver seu presente, ele a perdeu.

A realeza que pôde ser vencida pelo canto essa mesma realeza poderá ser vencida pela força. ${ }^{6}$

Séculos antes, o alexandrino Eratóstenes de Cirene (segunda metade do séc. III a. C.), no catasterismo no 24 ("Lira"), de seu livro Mitologia do firmamente, explicava como a lira de Orfeu, após sua morte, foi elevada aos céus, tornando-se desde então a constelação da Lira. O famoso instrumento musical, como se sabe, foi inventado por Hermes e dado de presente a Apolo, que logo o repassou a Orfeu, o qual teve a brilhante ideia, segundo Eratóstenes, de elevar o número de cordas da lira de sete para nove, em justa homenagem às Musas. O autor esposa a tese de que Orfeu foi morto e estraçalhado pelas bacantes (Bassárides, no caso, pois Eratóstenes se reporta a uma obra de Ésquilo que trata do assunto, mas que nos chegou muito fragmentariamente) por ter trocado o culto de Dioniso

\footnotetext{
${ }^{6}$ Sêneca 2014: 58-59.
} 
pelo de Apolo, quando se sabe que há muitas variantes da causa mortis de Orfeu, conforme se tentará mostrar. Por ora, tem-se o texto do mitógrafo:

Orfeo fue muy apreciado entre los hombres, hasta el extremo que se sospechava que embelesaba a las fieras y hasta a las piedras con su canto.

Orfeo dejó de honrar a Dioniso y empezó a venerar a Helio como si fuera el principal dios, al que también llamaba Apolo. Una noche se desveló y al amanecer se dirigió al monte Pangeo para contemplar la salida del Sol, a fin de ser el primero en ver al dios Helio. Ésta fue la causa de que el dios Dioniso, irritado, azuzara contra él a las Basárides (así lo cuenta el poeta Esquilo), que lo despedazaron y desperdigaron cada uno de sus miembros. Más tarde, las Musas los reunieron y les dieron sepultura en un lugar llamado Libetra. ${ }^{7}$

Mais de dois milênios depois, o poeta brasileiro Murilo Mendes (19011975) valeu-se repetidamente do mito de Orfeu (e Eurídice) e chegou a tematizar a morte violenta do vate lendário em dois poemas de Parábola (livro composto entre 1946-1952 e publicado em Poesias, 1959), dos quais destaco o seguinte:

"Orfeu desolado"

Antigas de púrpura, Bacantes me dilacerais

Com gritos vermelhos

De hoje e outrora, Bacantes em espuma e fúria.

Abandonado pelo Canto

Vossas garras afiei,

Bacantes urlantes:

Insone poeta me arrasto

Em túnel de sombra e ruínas.

Meu coração feristes

Com mil agudos lanhos,

De todo abismo surgindo,

Bacantes em coro cortantes:

Metal e cinza gostei.

Bacantes, a lira lamenta

O mar limítrofe,

$O$ vento vermelho que a mantinha.

\footnotetext{
${ }^{7}$ Eratóstenes 2012: 81.
} 
Eurídice! Eurídice!

Casta coluna perdida

Entre mármores atômicos:

Que os elementos se alterem,

Troquem suas propriedades

Para que sob o céu dissolvido

E montanhas recuando eu te abrace,

Mesmo inútil, já desfeito,

Mãos de órbitas vazias,

Transpondo sem lâmpada o Aqueronte

Sob o silvo das antigas

Bacantes. ${ }^{8}$

Os breves excertos dão a ver os modos pelos quais a literatura (mas também a filosofia e a mitografia) exploraram os quatro mitemas fundamentais da narrativa de Orfeu; mitemas que serão estudados à frente, com mais detença, no desenrolar do presente trabalho. Este, doravante, se dividirá em quatro movimentos que se repetirão na variação de seus temas e motivos sobre Orfeu (ou sobre Orfeu e Eurídice).

\section{MOVIMENTO}

As poucas transcrições já revelam porque Pierre $\mathrm{Brunel}^{9}$, em seu Dicionário de mitos literários, afirma que o mito de Orfeu "é um feixe de contradições", pois multifárias são as suas representações de poeta lendário, músico, filósofo, amante dedicado, sacerdote, adivinho, fundador religioso... Pode-se acrescer, a tal "feixe de contradições", o fato de o mito de Orfeu, cuja história patética até hoje repercute em nossa sensibilidade, revestir-se de evidente cosmopolitismo, pois foi (é) tema e motivo de todas as artes e contínuo ponto de reflexão para a filosofia, as ciências sociais, a própria literatura. Objeto privilegiado para a intertextualidade, a intersemiose e os estudos interculturais, o mito trácio, nascido filho da musa Calíope e do rei-rio Éagro (segundo a maioria das fontes), passou por várias metamorfoses e sofreu o impacto de apropriações várias, em variadas culturas, em tempos e espaços descontínuos, que vão das civilizações mediterrâneas antigas, passam pela Idade Média e o Renascimento, pela Espanha do Siglo de oro ou pelo Brasil colônia, e chegam ao Modernismo e à cultura global da atualidade, atingindo inclusive a indústria cultural de massa. Isto quer dizer, em termos da chamada "escola alemã" de literatura comparada, que o mito de Orfeu sofreu várias migrações e transmigrações, passando da mitologia propriamente

\footnotetext{
${ }^{8}$ Mendes 1995: 551-552.

${ }^{9}$ Brunel 2005: 766.
} 
dita para a literatura oral e/ou para a escrita, da erudita para a massiva, ou da mitologia e da literatura culta para as outras artes, sempre se considerando que tais processos migratórios se dão em temporalidades e espacialidades descontínuas, uma vez que o tratamento dado a Orfeu (ou a Orfeu e Eurídice), na Idade Média ou no século XVII barroco, p. ex., difere consideravelmente entre si, pois outro é o momento histórico, a ideologia, a tensão social, a concepção estética. No caso português, as figuras históricas de Inês de Castro e D. Sebastião são exemplares das migrações de que trato aqui, tendo sido muito diversas as maneiras por que foram explorados pela poesia, pela narrativa e pelo drama português, desde o Humanismo. No caso do rei e do Sebastianismo, nos tempos que correm tem havido uma verdadeira febre de desconstrução e dessacralização de seus significados histórico-culturais, míticos e literários por parte da narrativa e da arte portuguesa contemporânea.

Em relação a Orfeu, sua história é a do mito primevo (ou mito arquetípico, com o quero significar o mito fundador de alguma atividade humana, no caso a poesia e a música, essenciais na educação grega) transformado, de algum modo, em protótipo (o modelo ideal do poeta lírico, tal qual a tradição literária acostumou-nos); em personagem (nas várias narrativas literárias, teatrais ou fílmicas em que Orfeu comparece); em tipo literário, social e/ou histórico (no Siglo de oro espanhol, por exemplo, quando passa a encarnar o marido zeloso); ou em estereótipo (na cultura massiva atual, se considerarmos o desenho animado japonês Cavaleiros do Zodíaco, que tem entre seus personagens um "Orfeu de Lira"). Constata-se, portanto, que o mito narrado no relato mitológico difere bastante do Orfeu feito personagem no filme de Jean Cocteau, ou no drama Orfeu da Conceição, de Vinicius de Moraes, ou no longo poema de Jorge de lima, Invenção de Orfeu. Perseguir tais variações e variedades de Orfeu - éticas e estéticas -, com vistas a um catálogo universal e infindável, seria cansativo e pouco acrescentaria a uma concepção moderna de pensamento órfico, sobretudo na poesia, e portanto não faz parte de minhas cogitações. Mas refletir e tentar conceituar claramente tais categorias (mito, arquétipo, protótipo, personagem, tipo, estereótipo) pode ser interessante porque ajuda a compreender o modo pelo qual Orfeu foi apropriado por esta ou aquela cultura, neste ou naquele momento histórico, por tal ou qual arte ou saber humano, sincrônica e diacronicamente. Nesta linha, portanto, a fim de não nos perdermos no labiríntico entramado órfico, continuemos a tecer alguns pontos sobre mitologia e literatura, sobretudo, mas tangenciando a filosofia e a religião antiga.

\section{MOVIMENTO}

Em termos mitológicos e literários, quatro são os mitemas que fundamentam a narrativa mítica de Orfeu: a) ele participa da viagem dos Argonautas em busca do Velocino de ouro; b) casa-se com a ninfa Eurídice, mas esta logo lhe é 
arrebatada pela morte; c) em famosa catábase, Orfeu desce ao Hades para reaver a amada dos deuses infernais: consegue-o, mas sua desobediência ao interdito de não olhar para trás leva-o a perder Eurídice pela segunda vez, definitivamente; d) enfim, Orfeu é morto e esquartejado pelas enciumadas bacantes da Trácia, seja porque teria vedado às mulheres o acesso aos mistérios órficos; seja porque a estas passa a preferir a companhia dos rapazes, inconsolável com a perda de Eurídice; seja porque, ainda, teria trocado o culto de Dioniso pelo de Apolo.

No esquema sempre sobressai o Orfeu músico-poeta portador da lira, cujo poder de sedução e encantamento domina animais, pedras, plantas, homens e deuses. Mas os quatro mitemas apontam também para uma configuração em gérmen dos gêneros literários, pois o primeiro é nitidamente épico e os três restantes conotam aspectos líricos e dramáticos do ciclo mítico. Friso esta questão problemática dos gêneros literários, presente em gérmen também no livro III da República de Platão e desenvolvida mais amiúde por Aristóteles, na Poética, porque penso que a realidade exemplar dos mitemas “vividos” por Orfeu corrobora e ultrapassa o conceito negativo da mímesis platônica, pois a conforma não como imitação superficial da natureza e/ou de caracteres humanos em ação, mas a esclarece enquanto cosmovisão baseada neste ou naquele modo de vida e de relacionamento entre os homens: o Orfeu épico, pois, está em consonância com uma comunidade de heróis exemplares, que se juntam em torno do objetivo comum de inaugurar as perigosas viagens por mares nunca dantes navegados, em busca do precioso Velocino de ouro, quando então cada um se aferra a um rol geral de obrigações para o bom andamento da aventura: a Orfeu, além de marcar a cadência do ritmo dos remadores (entre os quais um Héracles), cabe o papel de sacerdote, de iniciador dos marujos nos mistérios, de elo entre homens e deuses, de chefe dos festejos no casamento de Jasão e Medeia e (talvez o mais importante) de vencedor no certame contra as Sereias, cujo canto aliciador é suplantado pela música de Orfeu, segundo se lê no poema épico Argonáuticas, de Apolônio de Rodes (séc. III a. C.), ou nos relatos mitológicos de Higino (Fábulas 14. 1; 14. 27; 14. 32) - autor que viveu entre 64 a. C. e 17 d. C. - e de Apolodoro (Biblioteca, Livro 1. 9; 1. 1-28), cuja obra é posterior ao ano 61/60 a. C. e não pode ser confundido com o gramático Apolodoro de Atenas.

Por seu turno, o Orfeu lírico nos apresenta um modo de vida e uma cosmovisão em que sobressaem não mais as atividades coletivas comuns, mas a personalidade tensa de um eu apartado dos seus, ensimesmado em conflito e/ou em solilóquio e por isto mais atento aos pensamentos íntimos e aos movimentos sutis da alma e do coração, seja em relação à condição humana e ao lugar que o homem ocupa no universo; seja em relação ao gozo e ao sofrimento de amor, em cantar festivo ou elegíaco; seja pré-ocupado sensitivamente com a relação pessoal que mantém com a natureza, o cosmo, o outro: como arquétipo (e depois protótipo) do poeta lírico, é esta imagem primordial que se tem de Orfeu, cujo canto (música e poesia; som e sentido; pensamento e imagem) era capaz de 
demover os deuses infernais (Hades e Perséfone) e subjugar as sedutoras Sereias, além de (repita-se!) mover animais, pedras e árvores para ouvirem o canto divino de nosso poeta, que ao falar de si, fala de (e a) todos os homens.

O Orfeu dramático, na linha seguida aqui, revela-se nos vários embates agonísticos que o bardo mantém com os deuses infernais (Hades e Perséfone), com as Sereias e com alguns heróis (poucos) durante a viagem da nau Argos. Tal refrega, apoiada na excelência da execução poético-musical, não contém ainda o diálogo, a dialética, a maiêutica socrática, calcada na ironia, ou o agón da filosofia e da tragédia, mas já deixa ver os conflitos que se estabelecem entre vontades contrárias, que lutam para atingir um objetivo, conseguir uma distinção ou impor uma razão maior que, no caso de Orfeu, se traduz na força misteriosa do canto poético que convence, move, comove ou demove a parte em contenda. Interessante apontar, ainda, que os embates de Orfeu dizem respeito à esfera pública (é pelo bem de todos os tripulantes da Argos que ele luta com as Sereias, vencendo-as) e à esfera privada (é por interesse pessoal que ele tenta resgatar Eurídice do Hades, em refrega com os deuses subterrâneos), questões que serão fulcrais mais adiante, na tragédia e na comédia, porque o teatro (e a filosofia) é fruto precioso e especialíssimo da pólis grega. Já se disse que Orfeu vence na esfera pública e é derrotado na esfera privada, pois, ainda que consiga reaver a amada, infringe o interdito dos deuses e a perde pela segunda vez, em definitivo. A bybris órfica parece acarretar ainda mais violência e sofrimento para o herói, cujos dias se findam em cruel esquartejamento, embora este signifique uma revivescência ritual do trucidamento de Dioniso Zagreu e termine por conduzir Orfeu à salvação e à consagração na Ilha dos Bem-Aventurados (ou nos Campos Elíseos, dependendo da versão do mito), agora na companhia amorosa de sua Eurídice.

Tema constante da poesia lírica, a morte de Orfeu foi menos explorada pelo teatro, que preferiu enfocar o dramatismo amoroso das figuras de Orfeu e Eurídice: dramatismo este potencializado no século XVII com o surgimento da ópera italiana (Monteverdi) e com a Comédia Nova espanhola (Lope de Vega, Calderón de la Barca), que renovou o teatro herdado da Idade Média e do Renascimento.

A proposta de articular os quatro mitemas do ciclo de Orfeu e os três gêneros literários básicos é um exercício de teoria literária e mitológica bastante estimulante, pois deixa ver, na estrutura mesma, como se articulam profundamente a narrativa mítica e a ficção literária, tome esta feição narrativa, lírica ou dramática. Porém, sabemos todos que, na prática (notadamente no mundo grego antigo), tais atividades são quase indissociáveis, e estão presentes no mundo divino e no humano: na Ilíada (1. 601-604), por exemplo, Homero assim narra o banquete dos deuses, em que não faltam atrativos de poesia e música:

Durante todo o dia, até ao pôr do Sol, estiveram em festa, e ao seu ânimo nada faltou no festim equitativo, 
nem a formosa lira, que Apolo empunhava, e as Musas, que cantavam alternadamente com a sua bela voz. ${ }^{10}$

É também da Ilíada (9. 186-189) a famosa passagem em que Aquiles, afastado das refregas da batalha, toma a si a lira e canta harmoniosamente, numa mostra aplicada dos efeitos da educação primorosa que recebera (a guerra e a arte - que, tempos depois, em relação a Cervantes e Camões, nos dirão do frágil equilíbrio entre a espada e a pena, com a sabida vitória desta):

[...] e encontraram-no a deleitar o seu espírito com uma lira harmoniosa, lavrada com requinte, sobre a qual passava uma barra de prata.

Tinha-a tomado para si, quando arrasara a cidade de Eécion.

Com ela deleitava o seu ânimo, cantando feitos gloriosos. ${ }^{11}$

Fora do Olimpo, e em tempos de paz, os palácios dos homens também são visitados pelo aedo (artista inspirado, sob possessão das Musas): no famoso canto primeiro da Odisseia (1.325-355), Fêmio canta o regresso funesto dos aqueus e é repreendido por Penélope, saudosa de Odisseu e ignorante de seus destinos, enquanto na quarta estância (4. 15-19) um poeta cantor anima o banquete de Menelau no limiar da chegada de Telêmaco e do filho de Nestor ao palácio:

Assim se banqueteavam, sob os altos tetos do vasto palácio, os vizinhos e amigos do ilustre Menelau.

Grande era o seu deleite: no meio deles cantava o divino aedo, acompanhado da lira; dois acrobatas, dançando ao som da música, faziam as suas evoluções entre os hóspedes. ${ }^{12}$

Cena similar se verifica na rica e ajardinada vivenda de Alcínoo, o rei dos Feaces que agasalha o suplicante Odisseu em sua volta para casa (Od. 8. 72-74):

Quando se saciaram de bebida e de comida,

A Musa inspirou o aedo a cantar a glória dos heróis;

A fama daquela gesta chegava já ao vasto céu: ${ }^{13}$

Enfim, saliente-se que os quatro mitemas da narrativa de Orfeu configuraram obras literárias nos três gêneros básicos, desde o período arcaico grego, mas com ênfase no helenístico e com novo impulso a partir da literatura latina (Virgílio, Ovídio, Valério Flaco...). Hoje, aos milhares de textos literários

\footnotetext{
${ }^{10}$ Homero apud Pereira 2009: 35.

${ }^{11}$ Homero apud Pereira 2009: 44.

${ }^{12}$ Homero apud Pereira 2009: 74.

${ }^{13}$ Homero apud Pereira 2009: 97.
} 
(poemas líricos, elegias, poemas dramáticos, dramas, tragédias, tragicomédias, comédias, contos, romances...) somam-se infindáveis peças de escultura, pintura, artes aplicadas e mosaicos, além de óperas, coreografias, filmes, histórias em quadrinhos etc., numa pletora que evidencia Orfeu, definitivamente, dos mais consagrados mitos do panteão grego, e sua amada Eurídice. Mas na poesia lírica moderno-contemporânea, acredito, ainda falta uma exploração compreensiva do que seja o mito e o pensamento órfico entre os nossos melhores poetas, pois Orfeu ainda é para eles arquétipo e protótipo, embora degradado e talvez sem função no também degradado e escuro mundo contemporâneo.

\section{MOVIMENTO}

No universo grego, o poder apaziguador e catártico da música (que, indissociavelmente ligada à poesia, à palavra, à voz, ao sentido, teria o condão de colocar o ouvinte em harmonia com a música das altas esferas, como acreditavam os pitagóricos) era fundamental na educação dos gregos, conforme já se frisou (pensemos no Platão da República e das Leis), e talvez seja essa a causa de vários autores enfatizarem no Orfeu poeta lendário uma espécie de herói civilizador, que ensinara aos homens um valor ético-estético inalienável, com isso afastandoos do estado de selvageria, do mesmo modo que Prometeu lhes presenteou com o fogo revolucionário. Outra não é a perspectiva do mitógrafo Heráclito (que teria vivido em torno do ano 100 d. C.), autor de Histórias Incriveis (capítulo 23, "Orfeu"):

De éste [Orfeu] se dice que conmovía las rocas, los árboles, las bestias y las aves.

Lo correcto sería decir que atrajo a la reverencia de los dioses a los hombres, que eran brutos y no conocían ni los usos ni las leyes, y que ganó aquella fama por haber exhortado a la piedad a quienes eran como rocas y árboles, gracias al encanto de sus palavras. ${ }^{14}$

Claro que a interpretação do autor é uma leitura racionalista e/ou alegórica do mito, na tradição de Paléfato e, principalmente, Evêmero, mas é razoável insistir que sua revisão enfatiza um aspecto caro do mito órfico, uma vez que a concepção de Orfeu como herói civilizador, educador e doador de cultura aos seres humanos, vencendo as forças da natureza e os instintos bestiais, é da máxima importância para a compreensão profunda do mito (e do arquétipo do poeta lírico) e de sua permanência como esteio de valores atemporais, que se ligam tanto à questão estética e educacional (poesia e música), quanto à questão ética de sublimidade/sublimação, transcendência, magia, espiritualidade. E este

\footnotetext{
${ }^{14}$ Heráclito 2009: 88.
} 
seria, sem dúvida, mais um aspecto do cosmopolitismo de Orfeu. Ou, em palavras de Aristófanes pela boca de Ésquilo (As rãs, v. 1030-1036), trata-se da nobre utilidade dos poetas, que ensinam ao mesmo tempo em que deleitam o ouvinte:

É assim que os poetas devem exercitar-se. E repara, desde início, como esses poetas nobres se tornaram úteis!

Orfeu ensinou-nos os mistérios e a abstenção do crime,

Museu, a cura das doenças e os oráculos; Hesíodo, os trabalhos da terra, a estação dos frutos, a lavoura. O divino Homero onde foi buscar a sua honra e glória, senão ao fato de ter ensinado coisas úteis: ordem de batalha, valentia, armaduras dos guerreiros? ${ }^{35}$

Insisto um pouco mais na linha racionalista da interpretação do mito e transcrevo abaixo mais dois exemplos: o primeiro é o capítulo 21 do compêndio de Heráclito (que, talvez, tivesse ambições educacionais), intitulado "Os que estão no Hades":

Se dice que Heracles bajó al Hades y regresó con Cerbero, y que Orfeo hizo lo propio con su mujer Eurídice.

Lo cierto es que, cuando regresaba alguien tras haber padecido en una ausencia prolongada y repleta de peligros, decían que se había escapado del Hades. Por ello aún ahora decimos que, quienes escapan a sufrimientos prolongados, viajes peligrosos y enfermedades inciertas, se han salvado del Hades. ${ }^{16}$

O outro exemplo nos vem de um mitógrafo bastante tardio, mas ainda adepto da leitura alegórica, que ficou conhecido como Anônimo Vaticano (séc. $\mathrm{V}$ d. C.?) e deixou um opúsculo também intitulo Histórias Incriveis. Neste, ele assim propõe a exegese da expedição dos Argonautas (capítulo 3, "O velo de ouro"), da qual participara Orfeu:

Cuentan que lo que se guardaba entre los colcos no era realmente una piel de oro (esto es cosa de los poetas) sino un libro escrito en piel que contenía instrucciones sobre cómo se ha de obtener oro mediante procedimentos químicos [alquímicos]. Por tanto es lógico que la gente de entonces lo llamaran 'de oro', por las capacidades que de él procedían. ${ }^{17}$

A insistência nos exemplos, menores e hoje talvez pouco conhecidos, não é gratuita ou leviana porque tal via de interpretação racionalista (que se contrapõe à voz maviosa - porém perigosa, lembra Cícero em Da natureza dos deuses - dos

\footnotetext{
${ }^{15}$ Aristófanes apud Pereira 2009: 386.

${ }^{16}$ Heráclito 2009: 87.

${ }^{17}$ Anónimo Vaticano 2009: 106.
} 
poetas de todas as épocas) surge muito cedo na tradição mitológico-literária grega, e pode beirar as raias da ironia, da crítica e da zombaria, inclusive intentando separar, de um lado, o que era crença cega e labor poético e, do outro, o que era conhecimento real, fruto da razão e do estudo.

Várias destas questões vão de encontro aos postulados de Carlos García Gual em Introducción a la mitología griega: para o estudioso, os poetas foram os verdadeiros guardiães e transmissores dos mitos gregos, soando-lhe bastante positivas a transformação e a alteração de sentido ocasionadas pelas reescrituras que esses mitos vão sofrendo ao longo do processo milenar de formação e consolidação da literatura grega, cujo acervo é depois transmitido a romanos e a quantos povos compõem o chamado mundo ocidental. Segundo García Gual, além deste primeiro fator (a mobilidade que a própria literatura possibilita à mitologia, que por sua vez a alimenta desde os primórdios), há a conjugação de outros dois: b) a aparição da escritura alfabética, que desde logo revolucionou a cultura grega ao fixar em textos escritos toda uma tradição oral, mesmo expondo a mitologia "[...] a la crítica y la ironía [...]" ${ }^{18}$, conforme se vê nos mitógrafos racionalistas citados acima; c) a aparição da filosofia física na Jônia do séc. VI a. C., que, desdobrada e aprofundada em novas correntes de pensamento, intentou "[...] dar una explicación del mundo y la vida humana mediante la razón, en un proceso critico de enfrentamiento al saber mítico." ${ }^{19} \mathrm{O}$ autor tem razão, pois a filosofia questiona, desde cedo, os diversos mitos gregos (veja-se Xenófanes, p. ex., que viveu entre os sécs. VI/V a. C.), buscando, a princípio, outras explicações para o surgimento e a constituição da natureza e do universo e, em seguida, debatendo e aprimorando questões ético-morais caras ao homem grego em sociedade. Porém, essa mesma filosofia se nutre dos mitos tradicionais e cria outros mitos, a exemplo do que faz Platão em incontáveis passagens de sua obra, conforme constata o estudioso:

Platón es un gran narrador de mitos, que son, en cierto modo, de su propia creación. Esas ficciones que llamamos, según el propio Platón hace, 'mitos' son una especie de recreaciones según una pauta poética tradicional. Cuando Platón nos refiere el viaje de las almas al Más Allá - en el Fédon, el Fedro y la República - está contando un mito, que, en buena medida, es de su propia invención; lo es, sí, en muchos detalles; pero, no obstante, es también un relato que cumple toda una serie de requisitos propios del género. Podríamos decir que esos relatos platónicos son como variantes de un tema mítico que, en su estructura básica, es mucho más antiguo que Platón. Un tema mítico que recobrará nuevas matizaciones en el cristianismo, donde aparece en muchos autores y con nuevos detalles en cuanto al viaje y el cielo y el infierno y toda la

\footnotetext{
${ }^{18}$ García Gual 2013: 39.

${ }^{19}$ García Gual 2013: 39.
} 
ambientación ultramundana, pero que tiene unas raíces muy hondas en la tradición helénica. Y que también habían explotado en su proselitismo mistérico otras sectas, como la de los órficos. ${ }^{20}$

A lição de García Gual (a ecoar Bernabé e Casadesús) é cristalina, por isso a citação na íntegra, à qual se pode acrescentar ainda os pré-socráticos Pitágoras ou Empédocles (autor dos poemas Sobre a natureza e Purificaçóes, que, depois da descoberta do papiro de Estrasburgo, tendem a ser vistos como um só poema), que têm, comprovadamente, relações e imbricações muito sérias com o tema em pauta da metempsicose e da imortalidade da alma. E todos os citados, Pitágoras, Empédocles e Platão, de um modo ou de outro, fazem uso livre de formulações do orfismo místico-religioso e pagam tributo à figura mítica do poeta Orfeu, pois este, além de exemplo da união libertária e libertadora de mitologia e literatura, na Grécia antiga, passa também por ter sido o fundador do culto de mistérios que leva seu nome, o Orfismo. O fato, improvável segundo Pierre Brunel $^{21}$, obscurece ainda mais a figura do poeta-amante, pois é outra camada traiçoeira que se acrescenta ao terreno movediço que sustenta a sua "biografia" de mito e personagem. Lembre-se, portanto, que o "feixe de contradições" que é Orfeu, conforme o qualificou Brunel, só faz apertar os seus intrincados nós górdios.

\section{MOVIMENTo}

Repita-se: além de arquétipo da poesia e da música, Orfeu seria fundador do culto de mistérios que leva seu nome, o Orfismo.

E acrescente-se mais um problema: teria havido um Orfeu filósofo, que ombreasse com algum pensador grego antigo?

A resposta imediata, para as duas questões, é a mesma: Não, evidentemente não houve um Orfeu fundador religioso ou um Orfeu filósofo, pois estamos no reino da mitologia e da simbologia, e a existência de Orfeu era questionada, já no mundo antigo, pela sagacidade de um Aristóteles ou de um Cícero. Embora o estoico Crisipo, na opinião do mesmo Cícero, tenha adaptado as histórias de/ sobre Orfeu (ou as dos poetas Hesíodo e Homero), para escrever, filosoficamente, acerca da natureza dos deuses.

Constata-se, pela breve informação final, que alguém, no mundo antigo (talvez já antes do séc. VI a. C., que é quando o poeta Íbico canta a fama do nome de Orfeu), sempre esteve a atribuir poemas e textos diversos, ou ideias e pensamentos, ao fictício Orfeu, talvez pela autoridade e antiguidade de seu nome e de sua condição de poeta lendário.

\footnotetext{
${ }^{20}$ García Gual 2013: 49.

${ }^{21}$ Brunel 2005: 766.
} 
Primeiro caberia, conforme enfatiza Alberto Bernabé no geral de sua obra, e em particular em Textos órficos y filosofia presocrática, a distinção desses vários tipos de textos órficos, e somente depois a tentativa de conceituação do Orfismo, uma vez que não há consenso entre os estudiosos do que seja, efetivamente, tal movimento místico-religioso e filosófico e o seu próprio raio de atuação: em termos espaciais, por exemplo, o Orfismo se estendeu do Mediterrâneo ao sul da atual Rússia, atingindo a Ásia Menor, a Magna Grécia e as costas da África, enquanto, temporalmente, talvez tenha se propagado dos séculos V-IV a. C. até o fim da Idade Antiga, por volta do séc. V de nossa era. Ou seja, cerca de mil anos de atividades descontínuas, talvez, mas que deixaram um legado importante e que conheceram o apogeu a partir do cosmopolita período helenístico. Este "legado importante", na opinião de Bernabé, inclui, grosso modo: a) textos "[...] que son atribuidos por la fuente que los transmite a Orfeo [...]"22; b) textos, passagens ou fragmentos "[...] que se refieren a doctrinas compartidas por los órficos en otras fuentes [...]"23; c) "En tercer lugar, textos epigráficos o papiráceos que manifiestan formas de pensamiento que pueden calificarse de órficas." ${ }^{24}$, como o famoso papiro de Derveni, descoberto apenas em 1962 e que tem revolucionado o estudo e a compreensão acerca do Orfismo. Para Bernabé, haveria ainda um quarto grupo de textos que, não sendo órficos, ainda assim apresentam "[...] huellas claras de doctrinas que podemos considerar órficas." ${ }^{25} \mathrm{Como}$ exemplos, o estudioso aduz algumas passagens de Platão, principalmente, mas também "[...] la cosmogonía mencionada en la parábasis de las Aves de Aristófanes o de fragmentos de trenos de Pindaro en que se habla de ciclos de reencarnación." ${ }^{26}$ Acrescentemos também passagens de algumas tragédias de Eurípides e parte da filosofia pré-socrática, sobretudo os poemas já referidos de Empédocles. Segue, todavia, a advertência criteriosa de Bernabé: "No son stricto sensu textos órficos, pero parodian o aluden a otros que si consideramos órficos. Es un material que deve tratarse con cuidado, pero que es sumamente interessante también. ${ }^{27}$ Logo em seguida, esclarece o estudioso:

A través de los testimonios externos observamos que existen dos niveles de textos órficos, unos, poéticos, y otros exegéticos de los primeros. Con el tiempo, los textos exegéticos, influidos por la filosofía, influirán a sua vez en

\footnotetext{
22 Bernabé 2004: 11.

${ }^{23}$ Bernabé 2004: 11.

${ }^{24}$ Bernabé 2004: 11.

${ }^{25}$ Bernabé 2004: 11.

${ }^{26}$ Bernabé 2004: 11.

${ }^{27}$ Bernabé 2004: 11.
} 
producciones órficas más tardias. ${ }^{28}$

Embora pouco mereça a atenção de Bernabé, cito um quinto grupo de textos órficos anônimos, atribuídos a Orfeu, que interessam a este trabalho porque promovem a confluência entre três atividades antigas importantes: a literatura, a mitologia e a religião órfica (bem como, tardios, ajustam-se ao postulado logo acima pelo estudioso espanhol). Trata-se de duas obras provavelmente localizadas entre os séculos IV-V de nossa era, os Hinos órficos e as Argonáuticas órficas: estas fazem a reescritura da viagem dos Argonautas tendo como protagonista Orfeu (e não mais Jasão), que narra a Museu os percalços da aventura; aqueles somam pouco mais de 83 hinos dedicados a divindades privilegiadas do panteão órfico (Dioniso, Perséfone, Hades, Hécate, Zeus, a Natureza...), que guardam certa similaridade com os Hinos homéricos, embora de qualidade inferior. Tais obras, apesar das restrições que a elas se faça e ainda que pouco iluminem os limites imprecisos do Orfismo, merecem nossa atenção porque, ao menos do ponto de vista de uma "literatura menor" (e/ou de uma mitologia e/ou de uma seita eivada de lugares-comuns), estão a evidenciar outros modos da recepção e da reescritura do mito de Orfeu, no final agônico da Antiguidade e num momento de afirmação contundente do Cristianismo - talvez sirvam, por isto, como "peças de resistência", mas isto se afirma aqui como hipótese de trabalho, pois precisa ainda de uma minuciosa investigação. Por outro lado, a tripla conexão literatura-mitologia-religião (+ filosofia) evidencia um cosmopolitismo interessante de ideias, práticas e conhecimentos que atravessaram séculos em trocas interculturais e interdisciplinares enriquecedoras, uma vez que é muito posterior, na História, a divisão racionalista da ciência e do conhecimento e o apreço pela especialização. Talvez nos caiba, hoje, separar o joio do trigo, mas é salutar constatar que nossa contemporaneidade tem propiciado novo impulso aos estudos sobre o Orfismo, antes olimpicamente deixado à margem.

É neste diapasão que Alberto Bernabé, na obra citada e em Platão e o orfismo, ocupou-se como ninguém do estudo das relações da filosofia antiga com a questão órfica, estabelecendo bases e métodos seguros de análise, separando e conceituando termos, debruçando-se sobre os textos para sua efetiva exegese, sedimentando e alargando o caminho para o estudioso futuro. Como os dois livros citados ofertam largueza de vistas ao interessado, e como me ocuparei de tais problemas no decorrer desta pesquisa, gostaria de aqui salientar apenas alguns pressupostos básicos do Orfismo, começando com os termos realísticos com que Junito de Souza Brandão, em sua Mitologia grega, busca esclarecer o problema ao menos em parte:

\footnotetext{
${ }^{28}$ Bernabé 2004: 13.
} 
Se Orfeu é uma figura integralmente lendária, o Orfismo é rigorosamente histórico. [...] havia na Hélade, desde o século VI a. C. ao menos, uma escola de poetas místicos que se autodenominavam órficos, e à doutrina que professavam davam-lhe o nome de Orfismo. Seu patrono e mestre era Orfeu. Organizavam-se, ao que tudo indica, em comunidades para ouvir a 'doutrina', efetuar as iniciações e celebrar seu grande deus, o primeiro Dioniso, denominado Zagreu. ${ }^{29}$

Vê-se, pelo excerto, que o culto órfico de mistério elegeu Dioniso como seu deus principal, talvez pelo fato de este ter tido duplo nascimento e dupla vida: o primeiro Dioniso (ou Dioniso Zagreu, filho de Zeus e Perséfone) foi trucidado e devorado ainda menino pelos Titãs, e de seu coração salvo por Atena, segundo variantes, Zeus pôde fecundar Sêmele, a mãe do segundo Dioniso, o deus da vinha, da embriaguez, da inspiração e do teatro, como o conhecemos. Reza a lenda que dos restos misturados de Dioniso Zagreu e dos Titãs (então fulminados por Zeus, em vingança) nasceram os homens, filhos do céu e da terra ao mesmo tempo - daí o dualismo que separa radicalmente corpo e alma entre os órficos, entre os quais o corpo é compreendido como cárcere da alma.

Segundo já se afirmou, apesar de suas origens muito antigas, é no cosmopolita período helenístico grego que haverá uma acentuada difusão do Orfismo como religião, a qual acentua agora o culto religioso pessoal, vincado pelos estudos e sumamente preocupado com o ser humano (e não mais com os deuses intransigentes), colocando-se então, definitivamente, como um questionamento e uma crítica da religião oficial da pólis grega. Em sentido complementar, por causa de sua preocupação com o homem individual, diz-se que o Orfismo é condizente com as filosofias do período voltadas para o ser humano (o Epicurismo e o Estoicismo), mas delas difere por voltar-se para a alma, o sagrado e a vida depois da morte.

Prática ritual, secreta e iniciática, o Orfismo difere do culto de Elêusis por ter deixado uma considerável tradição escrita e intelectual, inclusive com a interpretação e o comentário erudito de textos, conforme já se disse. O Orfismo é tido como prática civilizatória e de conhecimento esotérico que, através de regras rígidas de conduta, rituais de iniciação, regras de ascese, catarse e purificação, estudos e conselhos para o post mortem, buscava aparelhar o homem para o bem-viver e para o bem-morrer. Dentre seus outros preceitos conhecidos estão o vegetarianismo, o culto da natureza e a proibição de derramamento de sangue. A salvação do ser humano após a morte era o fim último das doutrinas órficas: por certo, este o motivo de os iniciados serem sepultados com tabuinhas ou lâminas de ouro, madeira ou osso contendo fórmulas poemáticas especiais que indicavam o reto caminho do reino da Bem-Aventurança. Portanto, o Orfismo, embasado

\footnotetext{
${ }^{29}$ Brandão 2011: 160; grifos e aspas do autor.
} 
em sua própria teogonia/cosmogonia, não excluía o ser humano, que na verdade estava no centro de seus interesses - por isso fala-se de uma antropogonia órfica, no sentido de que esta procurava revelar a origem mítico-divina do homem e também prepará-lo para a morte e para a busca da salvação além-túmulo, consoante já se afirmou. A escatologia órfica, assim, se ramifica para o passado e para o futuro, pois tenta esclarecer, através de suas várias teogonias, o princípio de tudo e de sua própria religião, além de pressupor um conjunto de preceitos através dos quais o homem reto, após a morte, pode alcançar a salvação ao final de seu calvário neste mundo de iniquidades.

Em suma, Brandão acentua como essenciais ao Orfismo a combinação de um tríplice aspecto (a cosmogonia, a antropogonia e a metempsicose), e o estuda demoradamente ${ }^{30}$. O verbete de seu manual de mitologia, contudo, deve ser tido como ponto de partida para estudos mais aprofundados e isentos sobre Orfeu e o Orfismo, pois tende a associar piamente as duas questões - como, de resto, vários outros autores acabam confundindo as duas matérias. Claro que a segunda decorre do mito, mas não se pode crer que este seja o fundador e o divulgador do Orfismo, que é, definitivamente, criação e construção cultural humana.

\section{FinALE}

À guisa de conclusão, saltemos para o séc. XVII inglês, a testemunhar mais uma tentativa de construção cultural humana a partir do mito de Orfeu, ora reinterpretado moral e alegoricamente pelo filósofo Francis Bacon (capítulo XI, "Orfeu, ou filosofia", de $A$ sabedoria dos antigos, 1609), que busca encontrar uma espécie de origem nobre para a filosofia:

A história de Orfeu, que embora muito conhecida não tem sido em todos os pontos interpretada corretamente, parece representar a Filosofia Universal. Pois Orfeu, homem admirável e verdadeiramente divino, que, senhor das harmonias, subjugava e arrastava após si todas as coisas graças às suas cadências doces e gentis, pode bem passar por uma personificação da filosofia. Assim como as obras do saber ultrapassam em dignidade e vigor as obras da força, os feitos de Orfeu superam os trabalhos de Hércules. ${ }^{31}$

Linhas adiante, após recapitular passagens da narrativa mítica, Bacon conclui: "Eis o provável sentido da fábula. O canto de Orfeu é de dois tipos: um deles propicia as potências infernais, o outro comove as feras e os bosques. Entende-se melhor o primeiro em referência à filosofia natural; o segundo, à filosofia moral

\footnotetext{
${ }^{30}$ Brandão 2011: 163-179.

${ }^{31}$ Bacon 2002: 46-47.
} 
e política." ${ }^{32}$ Páginas à frente, em outras reinterpretações alegóricas de mitos, o filósofo inglês novamente encarece Orfeu em relação a outros heróis, sempre do ponto de vista ético e moral: no capítulo XXXI, "Sereias, ou volúpia", ele contrapõe os dois remédios encontrados para vencer as Sereias, o de Odisseu e o de Orfeu, tomando o partido deste:

[...] o melhor em todos os sentidos é o de Orfeu, o qual, cantando e fazendo o elogio dos deuses, confundiu as vozes das Sereias e as deixou para trás. É que a meditação das coisas divinas supera os prazeres dos sentidos, não apenas em força, mas também em doçura. ${ }^{33}$

${ }^{32}$ Bacon 2002: 48.
${ }_{33}$ Bacon 2002: 98. 


\section{REFERÊNCIAS BIBLIOGRÁFICAS}

Anónimo Vaticano (2009), Historias increíbles, in J. B. Torres Guerra, (Introducción, traducción y notas). Mitógrafos gregos: Paléfato. Heráclito. Anónimo Vaticano. Eratóstenes. Cornuto. Madrid, 99-120.

Apolodoro (2001), Biblioteca. Introducción de Javier Arce. Traducción y notas de Margarita Rodríguez de Sepúlveda. Madrid.

Bacon, F. (2002), A sabedoria dos antigos. Tradução de Gilson César Cardoso de Souza. Apresentação de Raul Fiker. São Paulo.

Bernabé, A. (2011), Platão e o orfismo: diálogos entre religião e filosofia. Tradução de Dennys Garcia Xavier. São Paulo.

Bernabé, A. (2004), Textos órficos y filosofía presocrática: materiales para una comparación. Madrid.

Brandão, J. de S. (2011), Mitologia grega. Vol. II. Petrópolis. 20a ed.

Casadesús Bordoy, F. (2013), “Los relatos escatológicos en Platón: entre el logos y el mito", Humanitas 65: 71-87.

Cícero (2004), Da natureza dos deuses. Introdução, tradução e notas de Pedro Braga Falcão. Lisboa.

Eratóstenes (2012), Mitología del firmamento (Catasterismos). Introducción, traducción y notas de Antonio Guzmán Guerra. Madrid.

Ésquilo (1991), Oresteia (Agamémnon, Coéforas, Euménides). Tradução Manuel Pulquério. Lisboa.

García Gual, C. (2013), Introducción a la mitología griega. Madrid.

Heráclito (2009), Historias increíbles, in J. B. Torres Guerra (Introducción, traducción y notas). Mitógrafos gregos: Paléfato. Heráclito. Anónimo Vaticano. Eratóstenes. Cornuto. Madrid, 73-98.

Higino (2009), Fábulas. Introducción y traducción de Javier del Hoyo y José Miguel García Ruiz. Notas e índices de Javier del Hoyo. Madrid.

Mendes, M. (1995), Poesia completa e prosa. Organização, preparação do texto e notas de Luciana Stegagno Picchio. Rio de Janeiro.

Paléfato (2009), Historias increíbles, in J. B. Torres Guerra (Introducción, traducción y notas). Mitógrafos gregos: Paléfato. Heráclito. Anónimo Vaticano. Eratóstenes. Cornuto. Madrid, 11-72.

Pereira, M. H. da R. (Organização e tradução) (2009), Hélade: antologia da cultura grega. Lisboa. $10^{a}$ ed.

Sêneca (2014), A loucura de Hércules, in Sêneca. Tragédias. Tradução, introdução, apresentação e notas de Zélia de Almeida Cardoso. São Paulo, 1-103. 